
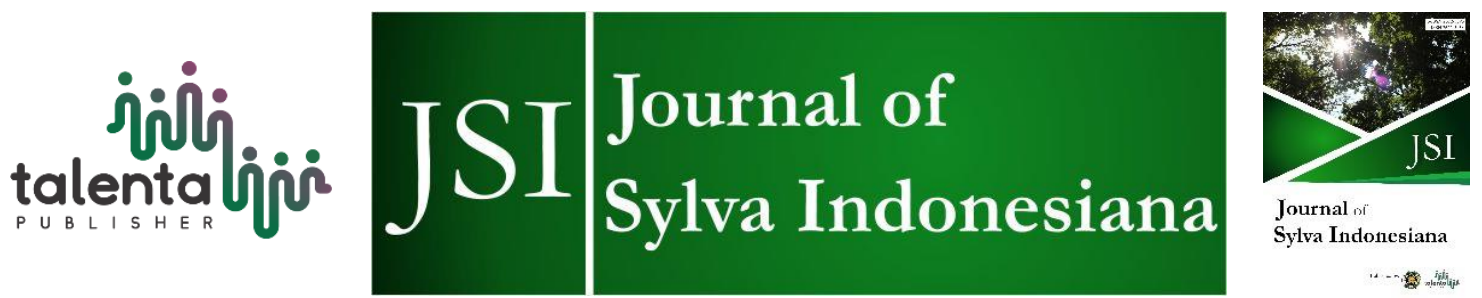

\title{
Mapping of Damar Mata Kucing (Shorea javanica) Plus Trees in Repong Damar Penengahan Village, Karya Penggawa Sub District, West Pesisir Regency, Lampung Province
}

\author{
Muhammad Ridwan', Afif Bintoro ${ }^{1}$, and Rahmat Safe' ${ }^{1}{ }^{*}$ \\ ${ }^{1}$ Major of Forestry, Faculty of Agriculture, University of Lampung, Bandar Lampung, Indonesia
}

\begin{abstract}
The distribution of seed and plus tree sources of damar mata kucing (Shorea javanica) in Repong Damar village is important to provide good quality of seeds. Currently, the existence of seed source of damar mata kucing is still unknown. Based on these conditions, it is necessary to mapping the seeds source or damar mata kucing plus trees. This study aims to analyze the plus tree map distribution using geographic information systems. This research was conducted using a survey method to determine the coordinates based on the growth location characteristics. Data analysis was performed using geographic information systems. The results showed that there were 24 plus trees (17.5\%) of the total population studied and distributed in 3 locations, namely east, north and west part. The plus tree distribution is mostly in the eastern part of $58.3 \%$, the northern part is $20.8 \%$, and the western part is $20.8 \%$. The growth location conditions in the eastern part have a slope of 5 $15 \%$, with an altitude of $41-121$ m.asl. In the western part it has a slope of $5-7 \%$, with an altitude of 40 - 73 masl and the northern part has a slope of $5-15 \%$, with an altitude of 35 174 masl.
\end{abstract}

Keyword: Mapping, Plus trees, Repong Damar

Received 13 June 2019| Revised 31 January 2021 | Accepted 17 February 2021

\section{Introduction}

Repong Damar in Pekon Penengahan has an area of 565 ha [1], or 3.22\%) of Lampung Province area [2]. Within a decade, the damar mata kucing production was decreased due to the tree age is more than 60 years old. Repong Damar on the west coast is owned by generation to generation, whose tree ages range from 20 years to more than 60 years [3]. Damar mata kucing trees to produce resin and become a productive tree. At the age of 20 year, damar mata kucing trees start for notched to produce resin [2].

\footnotetext{
*Corresponding author at: Major of Forestry, Faculty of Agriculture, University of Lampung, Jl Sumantri Brojonegoro, Gedung Meneng, Bandar Lampung 35145, Lampung, Indonesia

E-mail address: rahmat.safei@fp.unila.ac.id 
The process of reproduction and regeneration in Repong Damar takes quite a long time, so it is necessary to improve of damar mata kucing to produce superior seed sources in the future. The existence of a superior seed source is very important as a plantation forest development source and for increasing productivity [4]. One of the important seed source for these purpose id plus trees that are phenotypically selected and are better trees than the surrounding trees [5].

As technology advances, monitoring of plus tree can become easier to conduct with the integration of spatial data with vector data that can be easily aggregated. This unification of data is now known as the Geographical Information System (GIS). GIS is a computer-based system that has four capabilities in handling geographically referenced data, namely input, vector and spatial data management (data storage and recall), analysis and output of vector and spatial data [6].

Research on tree mapping plus Repong Damar in Pekon Penengah, Karya Penggawa District, West Pesisir Regency has never been conducted. Therefore, this research was conducted to obtain information about the distribution map of damar mata kucing trees plus (S. javanica) geographically in Pekon Penengah, Karya Penggawa District, West Pesisir Regency.

\section{Materials and Methods}

This research was conducted in June - July 2018 at Repong Damar Pekon Penengah, Karya Penggawa District, West Pesisir Regency. The tools and materials used in this research activity are scoring tables, GPS (Global Positioning System), laptops, Arc Gis software, Arc View tally sheets. The materials used are coordinate point of plus tree, Repong Damar land, West Coast administration map, contour maps, and land maps. The data collected includes primary and secondary data. Primary data includes scoring data and the coordinates of the plus tree, while secondary data includes data on elevation, slope, type of land and land ownership at the location of the plus tree.

\subsection{Field Data Collection and Measurement}

In this process the research location is determined, then the position is recorded. Before starting the search for coordinates, the GPS calibration is performed first. The calibration includes country setting (Indonesia), coordinate system (UTM), and WGS 1984. Each coordinate point is coded as an identity, on the plus tree (PP) candidate tree (PK), and comparison tree (PPB). The criteria for tree assessment are PP has a score of $>70$, PK has a score of $<70$, PPB has the criteria to be around the candidate tree within $5 \mathrm{~m}$ with a score of $<70$ which refers to the assessment criteria in Table 1 .

\subsection{Data Processing}

By using Excel software, this activity was carried out by entering the coordinate value of the plus tree from the measurement results in the field. Technical implementation was conducted by entering the plus tree scoring value which includes the tree height score, tree diameter $>20 \mathrm{~cm}$ for 
the criteria of a plus tree branch free stems, trunk shape, branch diameter, branch angle, pest resistance, natural pruning ability, and fruit production with coordinate points. This criterion refers to [7] as a reference for scoring the plus tree. The coordinate pairs were stored in the form of dbf (data base file) so that they can be input into Arc view in the Arc Gis software for overlay process. The scoring assessment criteria were presented in Table 1.

Table 1 Reference to scoring for plus trees identified at the research site

\begin{tabular}{|c|c|c|}
\hline $\begin{array}{l}\text { Phenotype } \\
\text { (1) }\end{array}$ & $\begin{array}{l}\text { Score (point)* } \\
\text { (2) }\end{array}$ & $\begin{array}{l}\text { Scoring (Point)* } \\
\text { (3) }\end{array}$ \\
\hline Tree height & $0,2,4,6,8,10$ & $\begin{array}{l}<5 \% \text { higher: } 0 \text { point; } 5-10 \%: 5 \text { point; } 10-15 \%: 4 \\
\text { point; } 15-20 \%: 6 \text { point; } 20-25 \%: 8 \text { point; }>25 \% \\
\text { higher: } 20 \text { point }\end{array}$ \\
\hline Stem diameter & $0,5,10,15,20$ & $\begin{array}{l}<5 \% \text { higher: } 0 \text { point; } 5-10 \%: 5 \text { point }, 10-15 \%: 10 \\
\text { point; } 15-20 \%: 15 \text { point; }>20 \% \text { bigger : } 20 \text { point }\end{array}$ \\
\hline Trunk without branches & $0,2,4,6,8,10$ & $\begin{array}{l}<30 \%: 0 \text { point; } 30-40 \%: 2 \text { point; } \\
\text { 40-<50\%:4 point } ; 50-<60 \%: 6 \text { point } \\
60-<70: 8 \text { point } ;>70 \%: 10 \text { point. }\end{array}$ \\
\hline \multicolumn{3}{|l|}{ Stem shape } \\
\hline Straigh & 30 & Stem Shape \\
\hline S-shaped & $-3,-7,-11,-15$ & Straight 5 -Shaped | Bow-Shaped j J-Shaped | Spiral | Fork \\
\hline Bow-shaped & $-3,-7,-11,-15$ & ${ }^{27}-1-1-1-1-1-1-1-1-1-1-1-1-1-1-1$ \\
\hline J-shaped & $-2,-3,-4,-5$ & 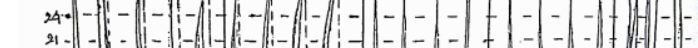 \\
\hline Spiral & $-5,-10,-15,-20$ & 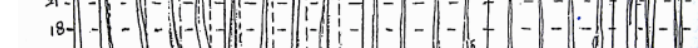 \\
\hline Fork & $-3,-7,0,-11,-15$ & 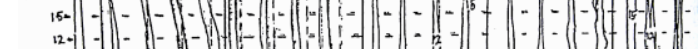 \\
\hline \multirow[t]{2}{*}{ Not cylindrical } & $-1,-2,-3,-4,-5$ & 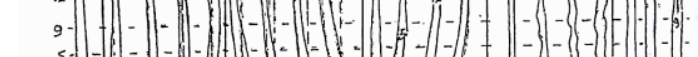 \\
\hline & & 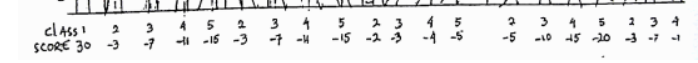 \\
\hline Branch diameter & $0,2,5$ & $\begin{array}{l}>50 \%: 0 \text { point; } 30-50 \%: 2 \text { point; } \\
<30 \%: 5 \text { point. }\end{array}$ \\
\hline corner of the branch & $0,2,5$ & $\begin{array}{l}<50 ": 0 \text { point } ; 50-70 ": 2 \text { point; } \\
>70 ": 5 \text { point. }\end{array}$ \\
\hline $\begin{array}{l}\text { Resistance to pests and } \\
\text { diseases }\end{array}$ & 0,5 & $>20 \%: 0$ point; $<20 \%: 5$ point. \\
\hline Natural pruning ability & $0,2,5$ & $\begin{array}{l}>50 \%: 0 \text { point; } 30-50 \%: 2 \text { point; } \\
<30 \%: 5 \text { point. }\end{array}$ \\
\hline Fruit production & 0,5 & Productive: 5 point; not productive: 0 point. \\
\hline
\end{tabular}

\subsection{Mapping of results}

The data obtained is processed in Arc View by inputting the dbf file data from the coordinates of each plus tree. Then import shape file data for the administration of the west coast district, the shape of the area of Repong Damar in Pekon Penengah and shape files for the boundaries of Pekon Penengah and Kecamatan Karya Penggawa. Then an overlay is carried out on the altitude raster data so that the location height data is obtained from sea level. The raster data is classified into 5 altitudes class, then overlay the slope raster data in order to obtain slope steepness data and divided into 4 slope classes.

After data entry was carried out, the layout is carried out by entering map attributes such as cardinal directions, map title, bar scale, text scale, legend, Map source and Universal Tranvers 
Marcator (UTM) grid system appropriate scale. When the process has finished, the command export the map layout to jpeg format.

\section{Results and Discussion}

\subsection{Spread of plus tree}

Repong damar has an area of 565 hectares with relatively wet humidity. The air humidity in this area ranges from 50-80\%. This causes high rainfall, ranging from 1500 to $2000 \mathrm{~mm} /$ year [8]. The northern repong damar area is at an altitude of 25-275 masl with a slope ranging from 0-45\% [8]. Taking coordinates in the Repong area using the GPS found 25 plus trees candidate and 112 comparison trees. Of the total trees found, only 24 met the plus tree criteria. The percentage of plus trees from the total trees found based on the survey was $17.5 \%$. Latitude and longitude coordinate data plus trees and prospective trees presented in Table 2.

Table 2 Coordinates of Candidate Trees and Plus Trees in Repong Damar Pekon Penengah, Karya Penggawa District, West Pesisir Regency

\begin{tabular}{|c|c|c|c|c|}
\hline \multirow[b]{2}{*}{$\begin{array}{l}\text { Candidate } \\
\text { tree number }\end{array}$} & \multirow[b]{2}{*}{$\begin{array}{l}\text { Plus tree } \\
\text { number }\end{array}$} & \multicolumn{3}{|c|}{ Growing Place Coordinates } \\
\hline & & ID Plus Tree & $\begin{array}{c}\text { Latitude } \\
\text { Coordinates (S) }\end{array}$ & $\begin{array}{c}\text { Longitude } \\
\text { Coordinates (E) }\end{array}$ \\
\hline$(1)$ & $(2)$ & (3) & $(4)$ & $(5)$ \\
\hline PK1 & not eligible & SHOJAV 1 & $5^{\circ} 8^{\prime} 3.767^{\prime \prime} \mathrm{S}$ & $103^{\circ} 56^{\prime} 29.737^{\prime \prime} \mathrm{E}$ \\
\hline PK2 & PP 1 & SHOJAV 2 & $5^{\circ} 8^{\prime} 5.345^{\prime \prime} \mathrm{S}$ & $103^{\circ} 56^{\prime} 33.353^{\prime \prime} \mathrm{E}$ \\
\hline PK3 & PP 2 & SHOJAV 3 & $5^{\circ} 8^{\prime} 5.877 " \mathrm{~S}$ & $103^{\circ} 56^{\prime} 35.997^{\prime \prime} \mathrm{E}$ \\
\hline PK4 & PP 3 & SHOJAV 4 & $5^{\circ} 8^{\prime} 5.582^{\prime \prime} \mathrm{S}$ & $103^{\circ} 56^{\prime} 39.593^{\prime \prime} \mathrm{E}$ \\
\hline PK5 & PP 4 & SHOJAV 5 & $5^{\circ} 7^{\prime} 39.939 " \mathrm{~S}$ & $103^{\circ} 56^{\prime} 39.740^{\prime \prime} \mathrm{E}$ \\
\hline PK6 & PP 5 & SHOJAV 6 & $5^{\circ} 7^{\prime} 44.544 " \mathrm{~S}$ & $103^{\circ} 56^{\prime} 17.507^{\prime \prime} \mathrm{E}$ \\
\hline PK7 & PP 6 & SHOJAV 7 & $5^{\circ} 7^{\prime} 44.867 " \mathrm{~S}$ & $103^{\circ} 56^{\prime} 16.979^{\prime \prime} \mathrm{E}$ \\
\hline PK8 & PP 7 & SHOJAV 8 & $5^{\circ} 7^{\prime} 43.054 " \mathrm{~S}$ & $103^{\circ} 56^{\prime} 16.250^{\prime \prime} \mathrm{E}$ \\
\hline PK9 & PP 8 & SHOJAV 9 & $5^{\circ} 7^{\prime} 42.541 " \mathrm{~S}$ & $103^{\circ} 56^{\prime} 17.879^{\prime \prime} \mathrm{E}$ \\
\hline PK10 & PP 9 & SHOJAV 10 & $5^{\circ} 7^{\prime} 26.447 " \mathrm{~S}$ & $103^{\circ} 57^{\prime} 10.612^{\prime \prime} \mathrm{E}$ \\
\hline PK11 & PP10 & SHOJAV 11 & $5^{\circ} 7^{\prime} 26.476 " \mathrm{~S}$ & $103^{\circ} 57^{\prime} 11.789^{\prime \prime} \mathrm{E}$ \\
\hline PK12 & PP11 & SHOJAV 12 & $5^{\circ} 7^{\prime} 14.900 " \mathrm{~S}$ & $103^{\circ} 57^{\prime} 16.251^{\prime \prime} \mathrm{E}$ \\
\hline PK13 & PP12 & SHOJAV 13 & $5^{\circ} 7^{\prime} 14.036 " \mathrm{~S}$ & $103^{\circ} 57^{\prime} 16.906^{\prime \prime} \mathrm{E}$ \\
\hline PK14 & PP13 & SHOJAV 14 & $5^{\circ} 7^{\prime} 14.267 " \mathrm{~S}$ & $103^{\circ} 57^{\prime} 17.409^{\prime \prime} \mathrm{E}$ \\
\hline PK15 & PP14 & SHOJAV 15 & $5^{\circ} 8^{\prime} 12.171 " \mathrm{~S}$ & $103^{\circ} 56^{\prime} 27.478^{\prime \prime} \mathrm{E}$ \\
\hline PK16 & PP15 & SHOJAV 16 & $5^{\circ} 8^{\prime} 11.201 " \mathrm{~S}$ & $103^{\circ} 56^{\prime} 28.383^{\prime \prime} \mathrm{E}$ \\
\hline PK17 & PP16 & SHOJAV 17 & $5^{\circ} 8^{\prime} 11.416 " \mathrm{~S}$ & $103^{\circ} 56^{\prime} 28.974^{\prime \prime} \mathrm{E}$ \\
\hline PK18 & PP17 & SHOJAV 18 & $5^{\circ} 8^{\prime} 10.382^{\prime \prime} \mathrm{S}$ & $103^{\circ} 56^{\prime} 28.275^{\prime \prime} \mathrm{E}$ \\
\hline PK19 & PP18 & SHOJAV 19 & $5^{\circ} 8^{\prime} 8.703^{\prime \prime} \mathrm{S}$ & $103^{\circ} 56^{\prime} 27.286^{\prime \prime} \mathrm{E}$ \\
\hline PK20 & PP19 & SHOJAV 20 & $5^{\circ} 8^{\prime} 7.103 " \mathrm{~S}$ & $103^{\circ} 56^{\prime} 29.689^{\prime \prime} \mathrm{E}$ \\
\hline PK21 & PP20 & SHOJAV 21 & $5^{\circ} 8^{\prime} 6.066^{\prime \prime} \mathrm{S}$ & $103^{\circ} 56^{\prime} 28.686^{\prime \prime} \mathrm{E}$ \\
\hline PK22 & PP21 & SHOJAV 22 & $5^{\circ} 8^{\prime} 4.580^{\prime \prime} \mathrm{S}$ & $103^{\circ} 56^{\prime} 29.352^{\prime \prime} \mathrm{E}$ \\
\hline PK23 & PP22 & SHOJAV 23 & $5^{\circ} 7^{\prime} 59.974 " \mathrm{~S}$ & $103^{\circ} 56^{\prime} 28.050^{\prime \prime} \mathrm{E}$ \\
\hline PK24 & PP23 & SHOJAV 24 & $5^{\circ} 7^{\prime} 59.025^{\prime \prime} \mathrm{S}$ & $103^{\circ} 56^{\prime} 28.675^{\prime \prime} \mathrm{E}$ \\
\hline PK25 & $\mathrm{PP} 24$ & SHOJAV 25 & $5^{\circ} 7^{\prime} 58.496 " \mathrm{~S}$ & $103^{\circ} 56^{\prime} 27.642^{\prime \prime} \mathrm{E}$ \\
\hline
\end{tabular}

Source: primary data (2018). Description: PK: Candidate Tree; PP: Plus Tree; SHOJAV: Shore $a$ javanica.

Based on Table 1, it can be seen that the coordinate points of all prospective trees are at Latitude (S) $5^{\circ} 7^{\prime} 14.267^{\prime \prime} \mathrm{S}-5^{\circ} 8^{\prime} 12.171^{\prime \prime} \mathrm{S}$, and coordinates of Longitude (T) $103^{\circ} 56^{\prime} 16.251^{\prime} \mathrm{E}-103^{\circ}$ 57' 16.906' E. Data processing using map processing software produces a map of candidate trees and comparison trees that are presented in Figure 1. 


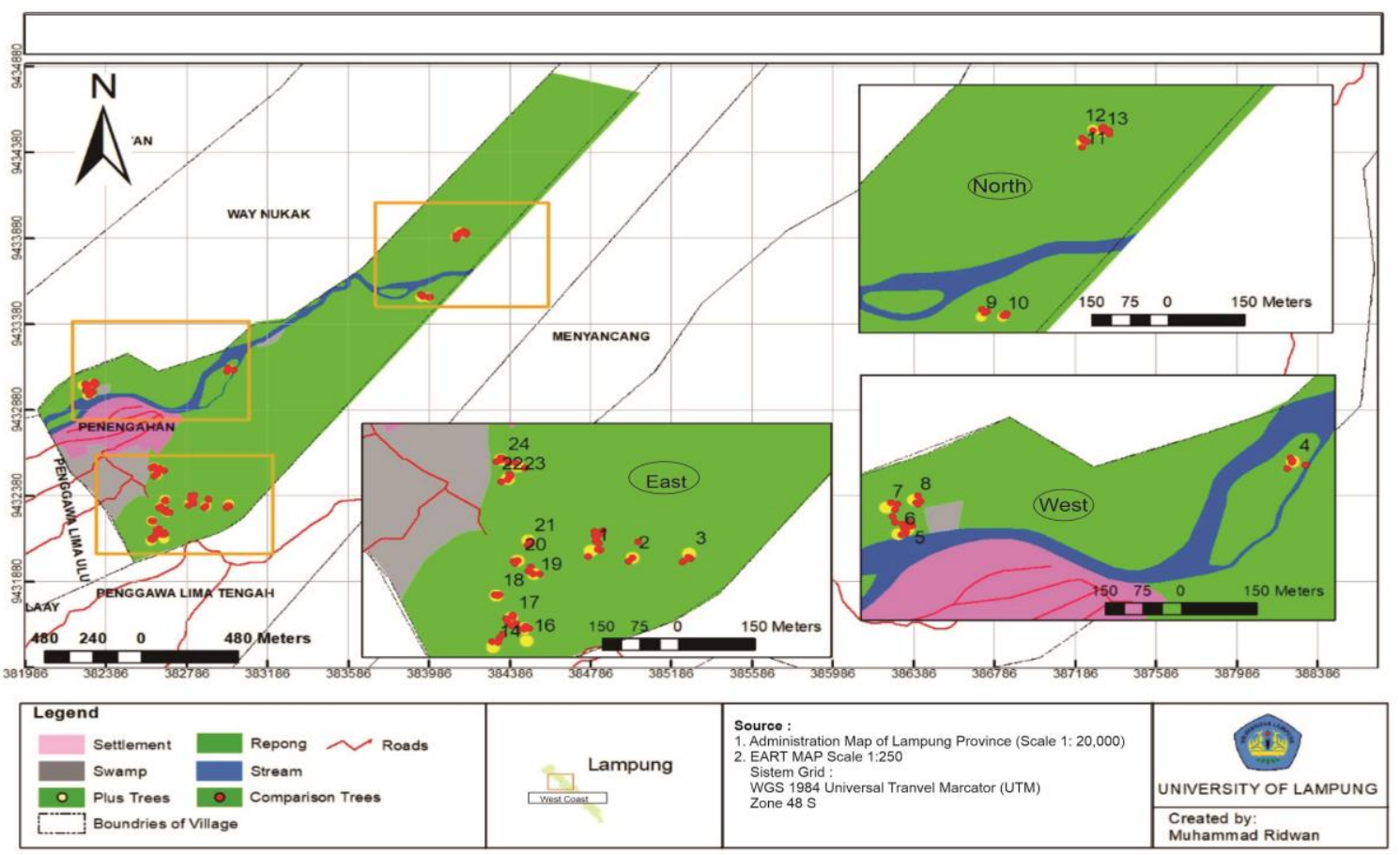

Figure 1 Distribution map of candidate trees and comparison trees

Based on the results of scoring and assessment, it can be seen that 24 plus trees were found in the research location. The plus tree is distributed over three parts, those were northern, western, and eastern parts. The distribution of plus trees in the three parts of the area is presented in Figure 2.

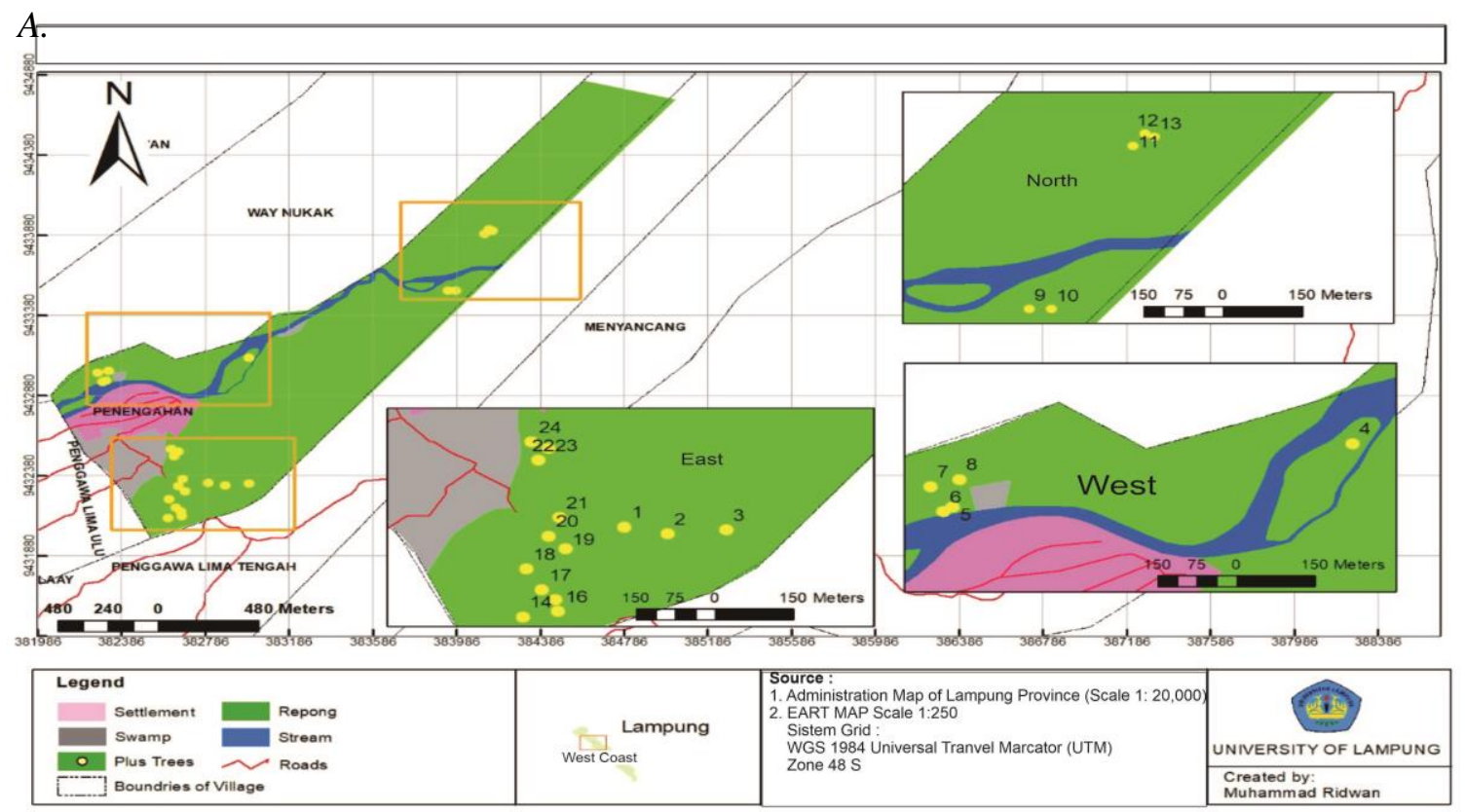

Figure 2 Distribution map of 24 plus trees in Repong Damar

Based on Figure 2, it can be seen that the highest number of plus trees is in the eastern part, which is 14 trees or $58.3 \%$ of the total number of plus trees found. The trees found are numbered 1-3 and $14-24$. In the western part there are 5 plus trees or $20.8 \%$ of the total plus trees that have 
numbers $9-13$. In the eastern part there are 5 plus trees or $20.8 \%$ of the total plus trees, with numbers 4-8.

\subsection{Mapping the Plus Tree}

The distribution of 24 plus trees is divided into 3 parts of the region, namely the western region, the eastern region, and the northern region. The plus tree in the each parts of the area has different scoring values. A scoring value recapitulation of 24 plus trees in each sub-region can be presented in Figure 3.

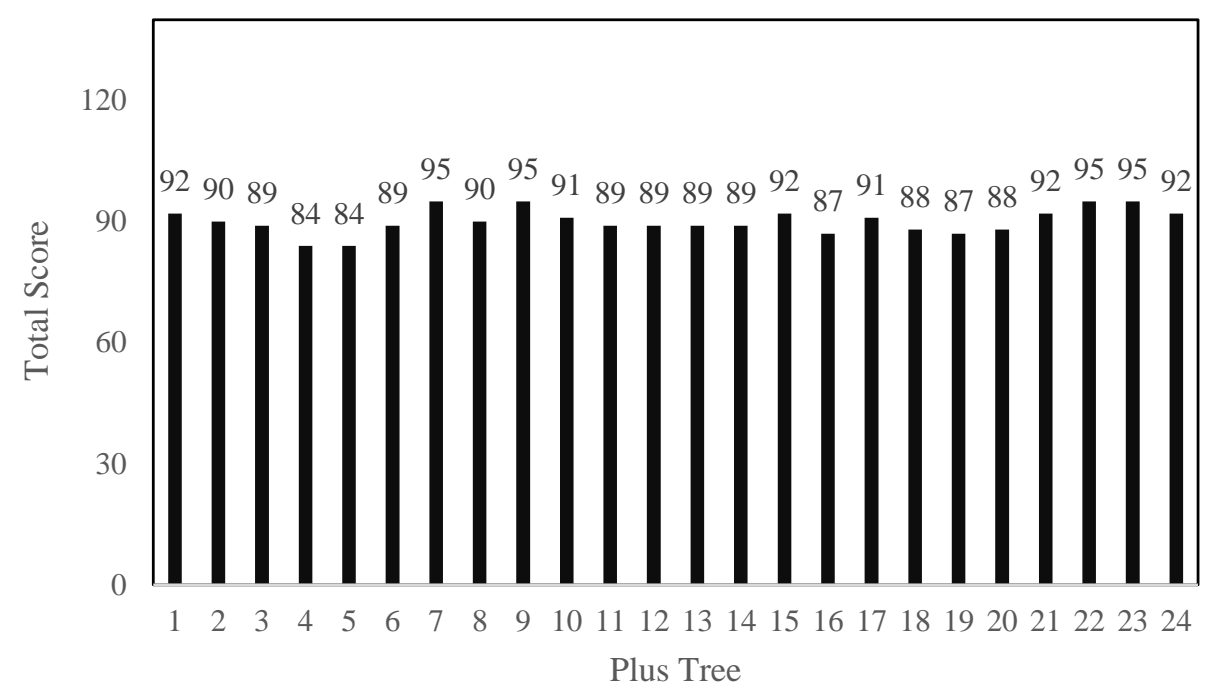

Figure 3 Diagram of the total score of the plus tree.

Based on Figure 3, it can be seen that the plus tree scoring has a interval value between 84-95. The sum shows that scoring $>90$ is $50 \%$ of the total 24 trees. In the eastern region it has a percentage of $57 \%$ of 14 trees, in the western region it is $40 \%$ of 5 trees, while in the northern region it is $40 \%$ of 5 trees. Of the 24 plus tree all the trees have met the scoring standard. The scoring criteria for plus trees are $>80[5]$.

Based on the results of observations and scoring assessments, it is known that as many as 24 plus trees found were classified as healthy and good quality trees. According to [9] stated that trees that are indicated to be sick or unhealthy will have an impact on a stand which affects growth rates, low crown conditions, and even cause tree death. The plus tree will be a good source of seeds, therefore the plus tree must have healthy conditions. According to [10], the health condition of forest stands is an indicator of forest health in various forest types.

The trees with the highest scoring value in the eastern region were trees number 22 and 23 with a value of 95. This value was given based on an assessment of tree diameter. According to [11] the diameter that must be had on a plus tree is at least $20 \mathrm{~cm}$. The size of the tree diameter plus is important considering that the product of this repong is resin. The bigger diameter of the resin 
trees, it more tapping holes that can be made. This will have an effect on increasing the productivity of resin from trees [12].

The plus tree with the highest value in the eastern region numbered 22 is found at a location with latitude $5^{\circ} 8^{\prime} 4.580^{\prime \prime} \mathrm{S}$ and longitude $103^{\circ} 56^{\prime} 29.352^{\prime \prime} \mathrm{E}$, while the plus tree numbered 23 is located at Latitude $5^{\circ} 7^{\prime} 59.025^{\prime \prime} \mathrm{S}$ and Longitude $103^{\circ} 56^{\prime} 28,675^{\prime \prime} \mathrm{E}$. The locations where the two plus trees grow are shown in Figure 4 and Figure 5.

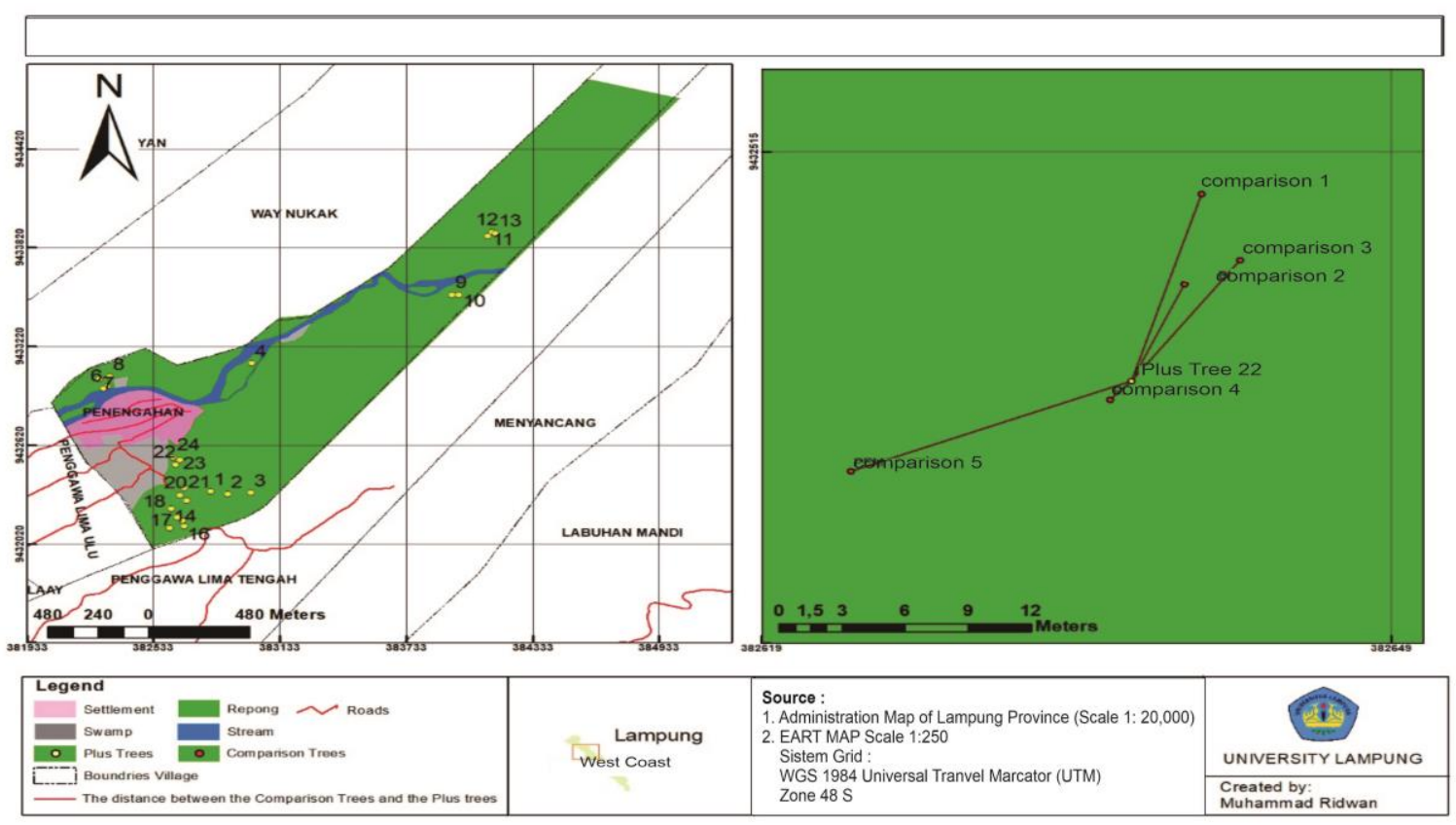

Figure 4 Map of plus tree location no. 22 on the east

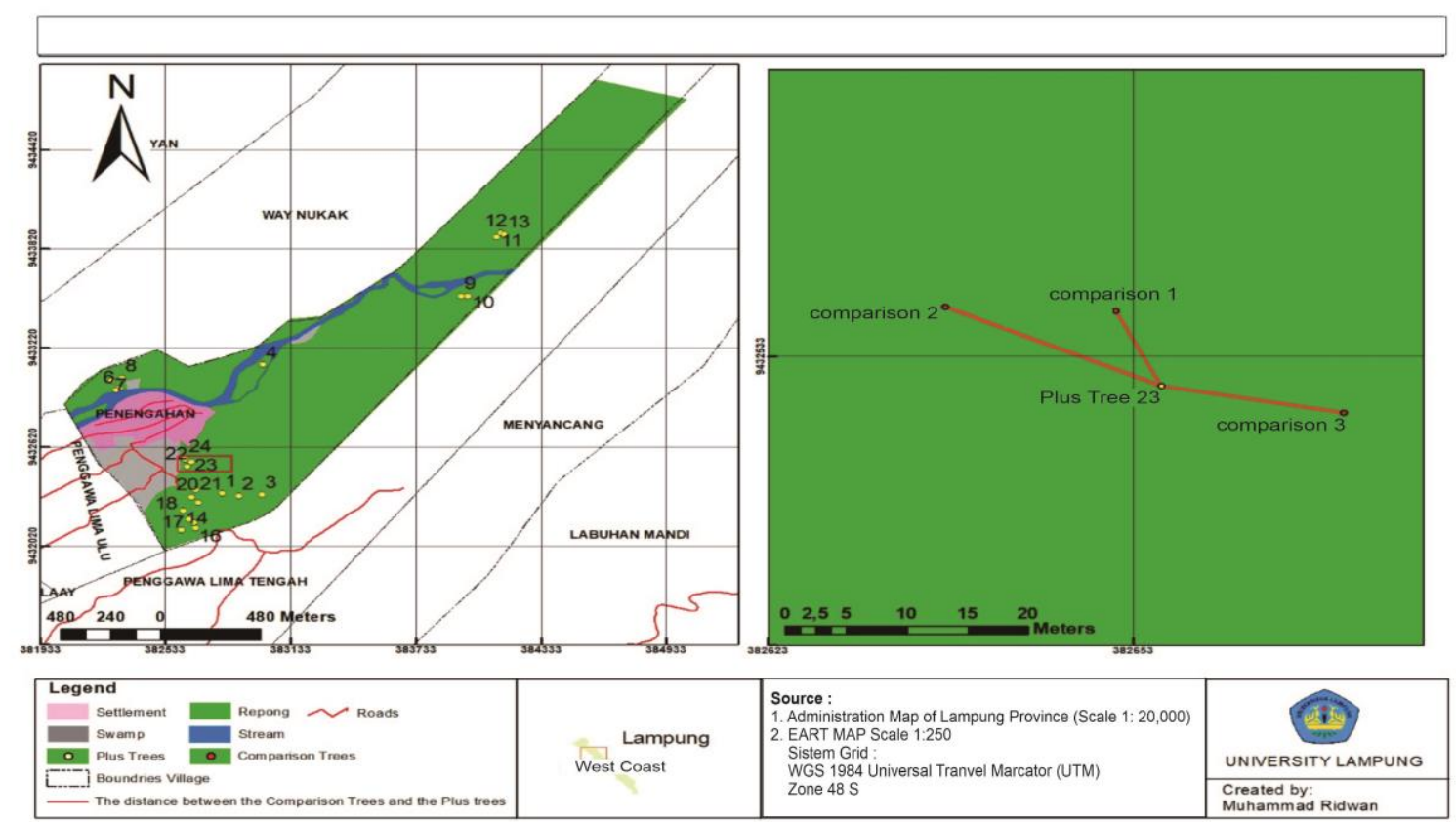

Figure 5 Map of plus tree location no. 23 in the eastern part 
The research found 5 plus trees growing and distributed in the western part. The five trees have a scoring value of 84-95. The percentage of the number of trees with a value $>90$ is $40 \%$, with a score of 95 and 90 . The plus trees are found in trees number 7 and number 8 . Both trees have a height $>30 \mathrm{~m}$, these criteria have met the standard as a plus tree. According to [13], the characteristic of a plus tree is that it has a height above $>20 \mathrm{~m}$. The locations of the trees growing plus number 7 and number 8 are presented in Figure 6 and Figure 7.

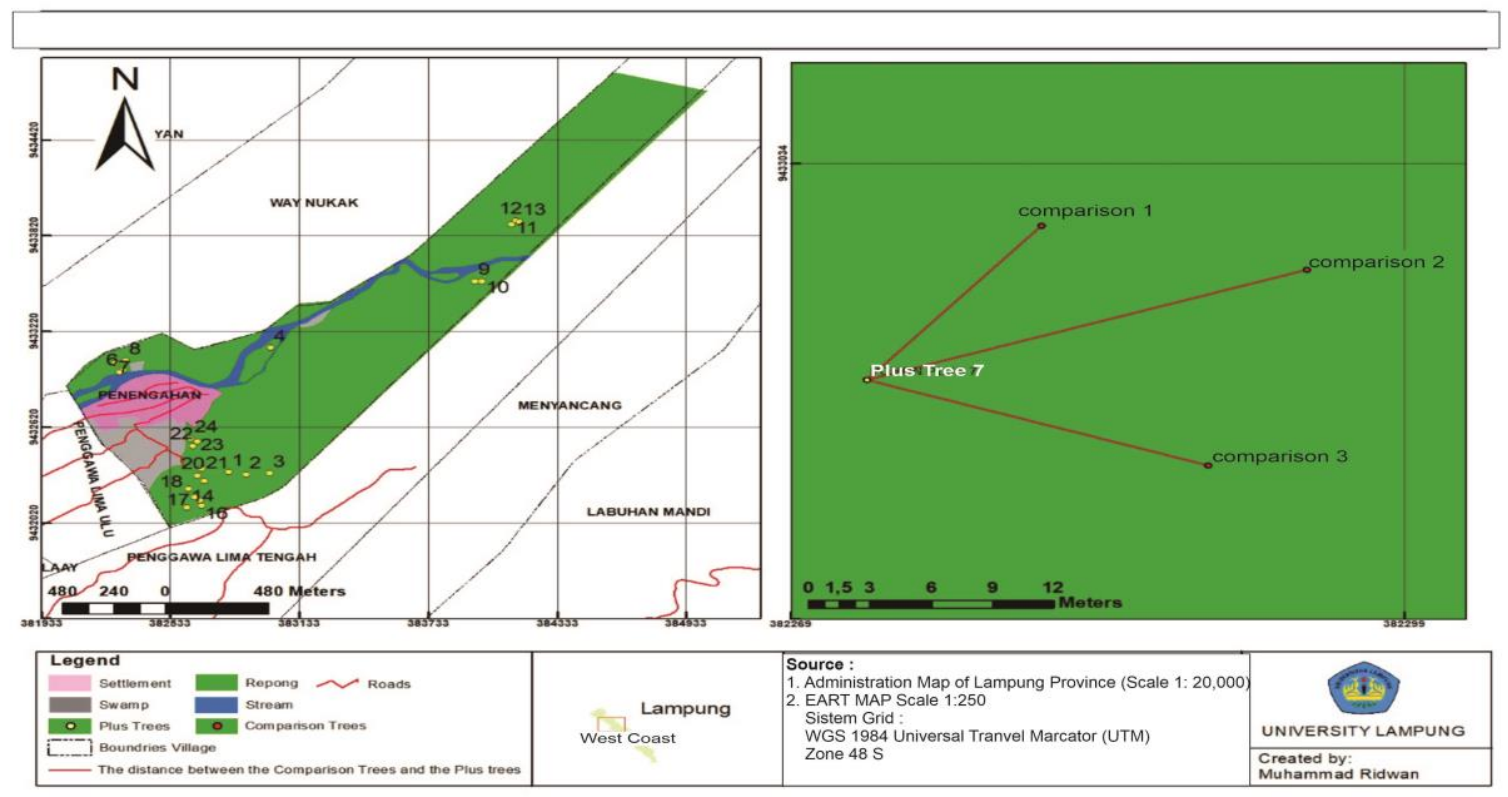

Figure 6 Figure 6 Map of plus tree location no. 7 in the western part

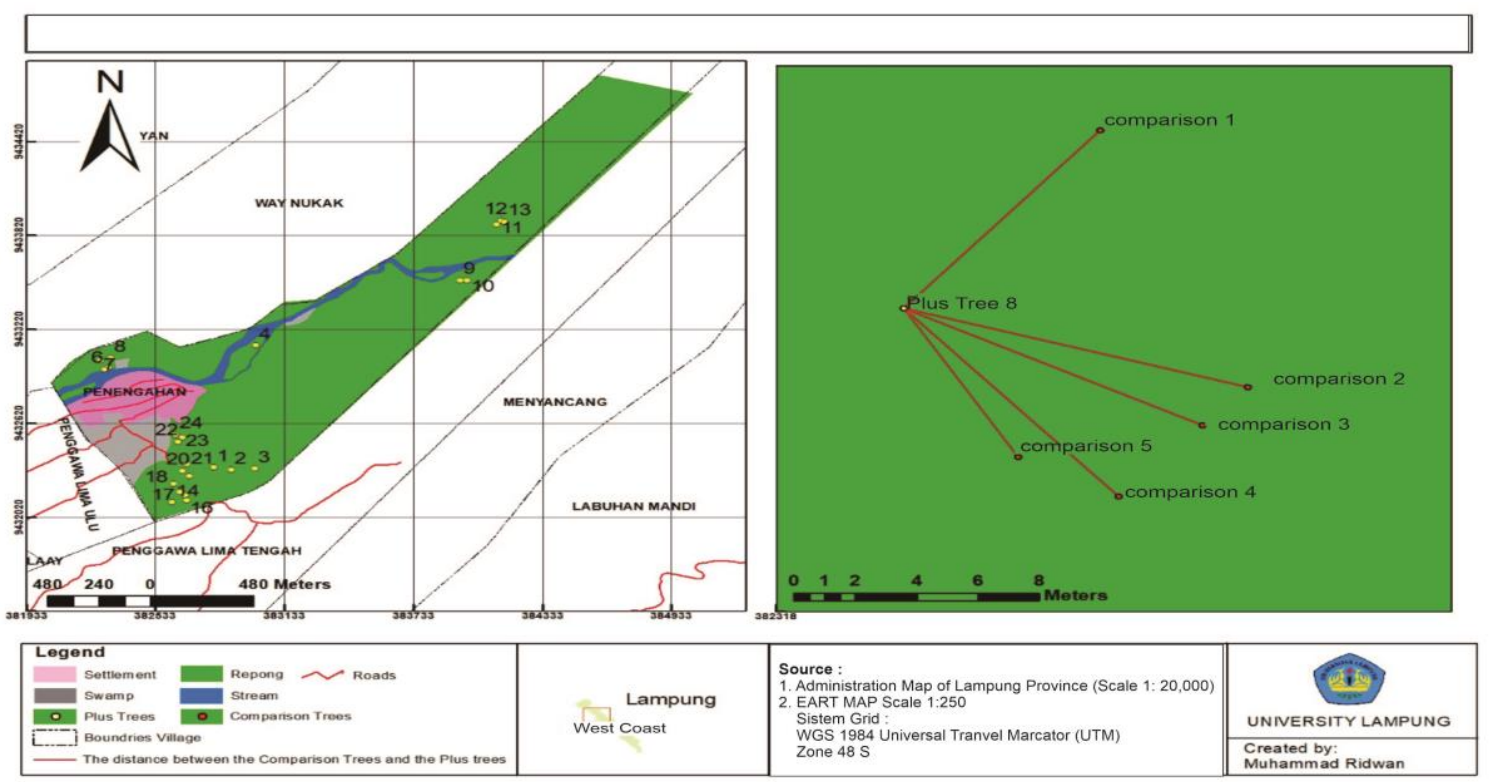

Figure 7 Map of plus tree location no. 8 in the western part

The results showed that there were 5 plus trees scattered in the northern part. The scoring values for the five trees ranged from 89 to 95 . The percentage of the scoring score 85 is $60 \%$, while the value $>90$ is $40 \%$. The difference in value was caused by the difference in the score of the tree 
trunk. The criteria of stem shape for plus tree must have is to have a straight stem at least $25 \%$ of the total tree height [14]. The highest scoring value is found in plus tree number 9 . The coordinates of the location where it grows are at Latitude $5^{\circ} 7^{\prime} 42.541^{\prime \prime} \mathrm{S}$ and Longitude $103^{\circ} 56^{\prime} 17,879^{\prime \prime} \mathrm{E}$. Map of the location of plus tree number 9 can be seen in Figure 9.

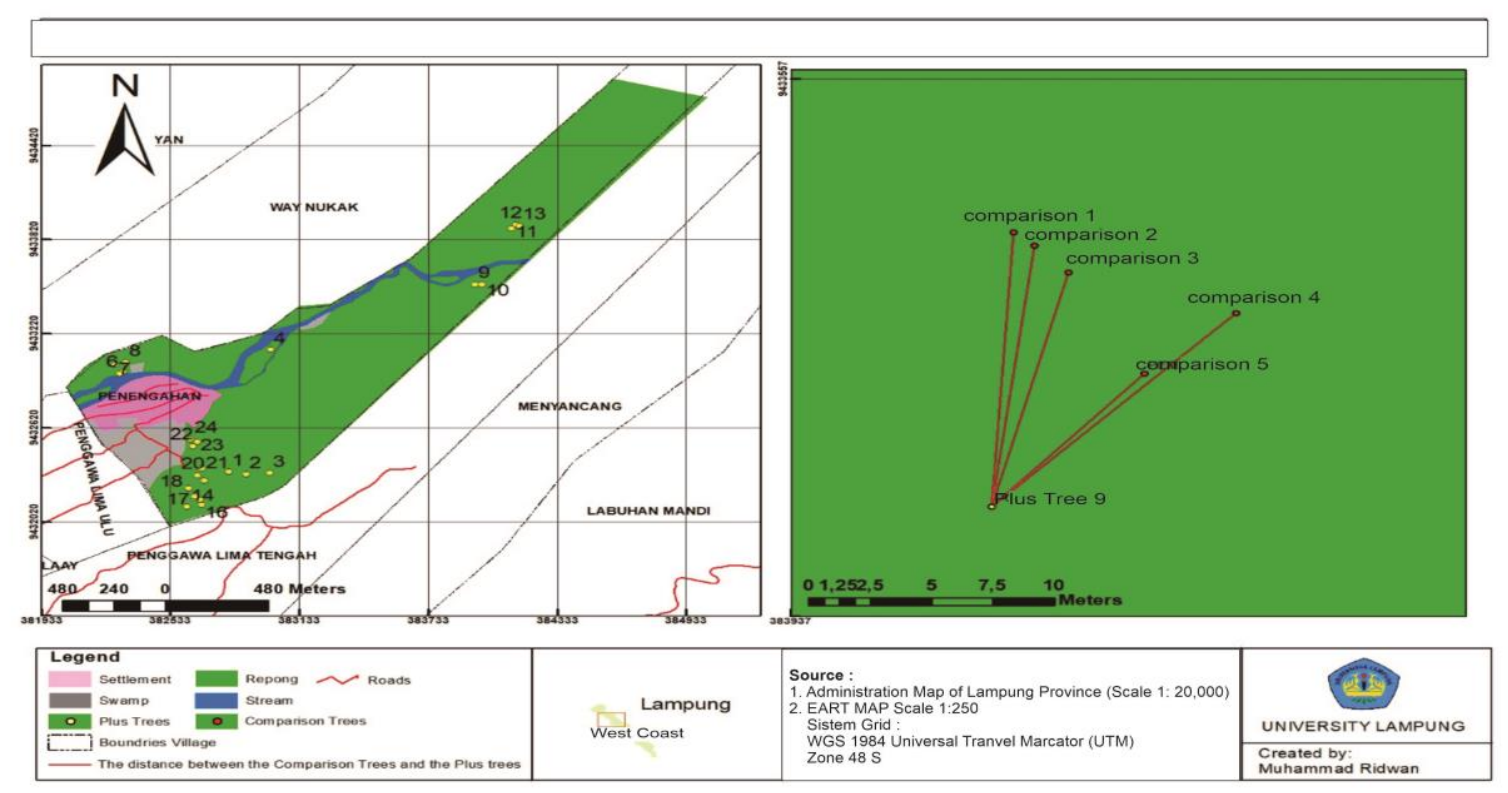

Figure 8 Map of plus tree location no. 9 in the northern region

\subsection{The condition of the location of the plus trees}

Based on the condition of the location where the plus trees grow, the area where 24 plus trees grow has an altitude between 35-174 masl. Plus tree number 3 is the tree that grows at the highest altitude, while tree number 5 is the plus tree that grows at the lowest altitude. The 24 plus trees at various altitudes were shown in Figure 9.

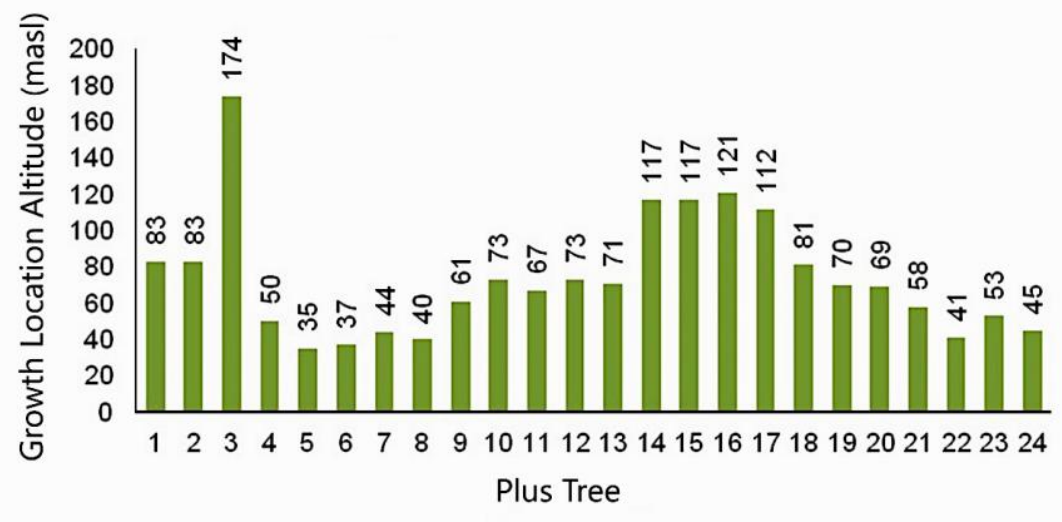

Figure 9 Histogram of 24 plus trees at various altitudes. 
Based on observations in the field, the altitude of the growing site in the eastern region ranges from 41-121 masl, in the western region ranges from 35-174 masl, while the northern region has an altitude ranging from 61-73 masl. The altitude of the site in Repong Damar Pekon Penengah is $<200$ meters above sea level [15]. The map of the altitude location of 24 plus trees is presented in Figure 10.

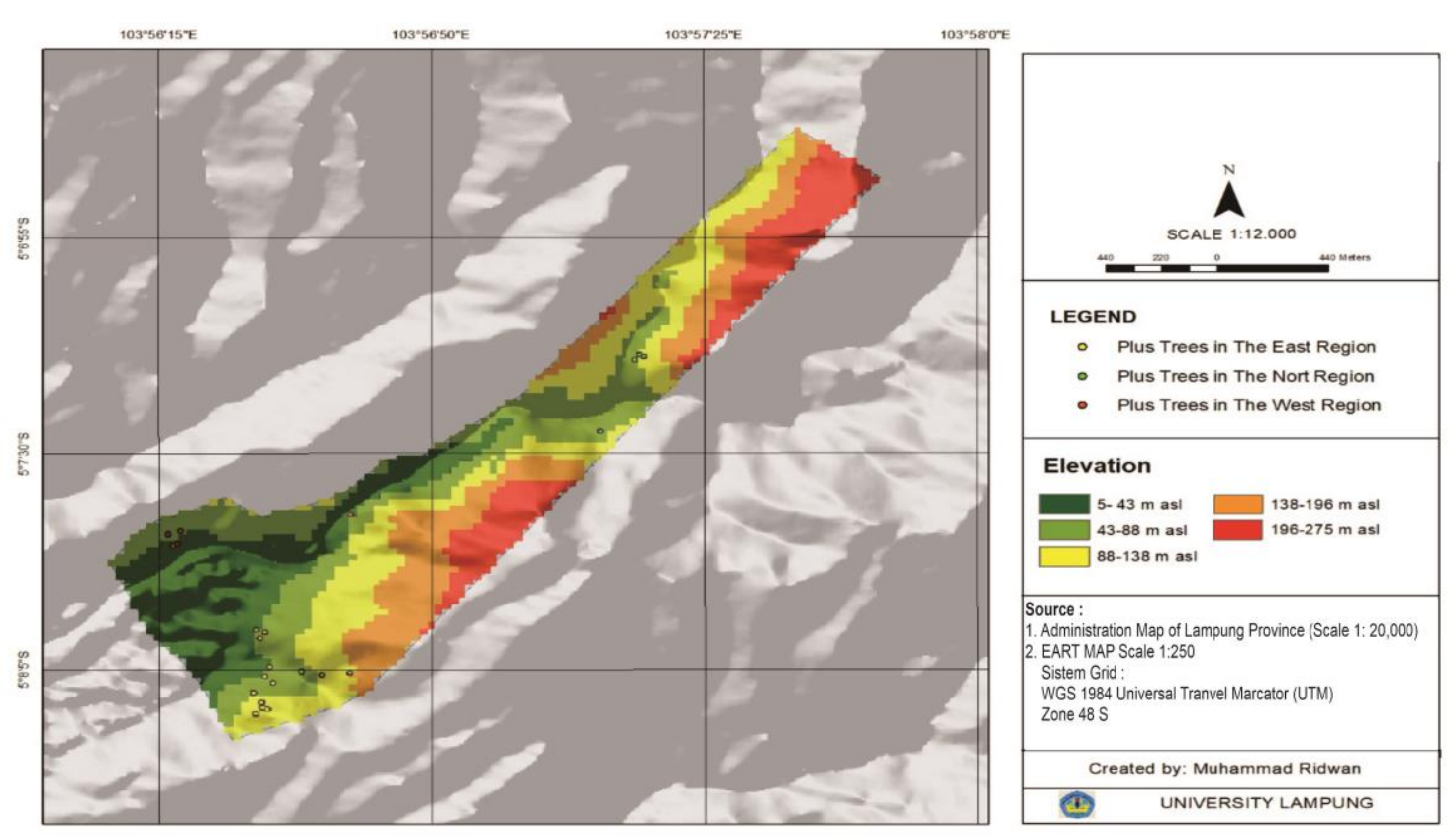

Figure 10 An overview map of the difference in altitude of 24 plus trees.

Based on the percentage of elevation in Figure 10, it is known that the area included in the category 5-43 masl is $16.6 \%$. Based on the data obtained, it can be seen that plus trees are often found on area with an altitude of 43-88 masl, which is $58.3 \%$. Land with an altitude category of 88-238 masl became the second place with the most plus trees, which was $8 \%$ land that has an altitude $>138$ masl is the land with the least amount of plus trees, which is only $4.1 \%$. Based on the slope data of 24 plus trees, it is known that the slope in the area varies from slightly to steep terrain. The difference in slope data for each tree is presented in Figure 11.

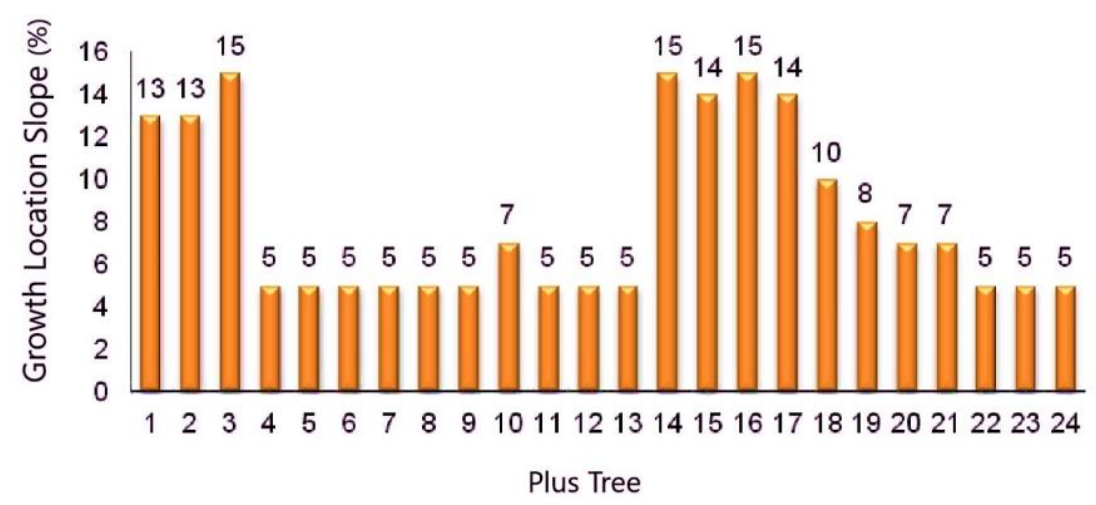

Figure 11 The diagram of the difference in the slopes of the 24 plus trees. 
Based on Figure 11, it can be seen that the eastern region is on a slope of 5-15\%. Plus trees were found growing on various slopes at the study site as many as 7 plus trees were found growing in the area bordering Pekon Menyancang, which is included in the flat category, 5 trees were found on land with a sloping category, and 2 plus trees were found growing on land with a slightly steep category. Observations in the western part of the Middle Pekon show that this region is an area that is located and has very close accessibility to the Middle Pekon. This area is a plus tree growing area with a dominant 5\% slope and only 1 tree that grows at $15 \%$ slope and is categorized as flat and sloping. Apart from the flat area, there are five plus trees in this area that produce a lot of seeds and has grown under the mother tree.

The condition of the growing site in the northern part of the region has a slope of 5-7\% is included in the flat area category. The northern region is bordered by the Bukit Barisan Selatan National Park, which is in a valley. A plus tree distribution map based on the altitude and slope of the area is presented in Figure 12.
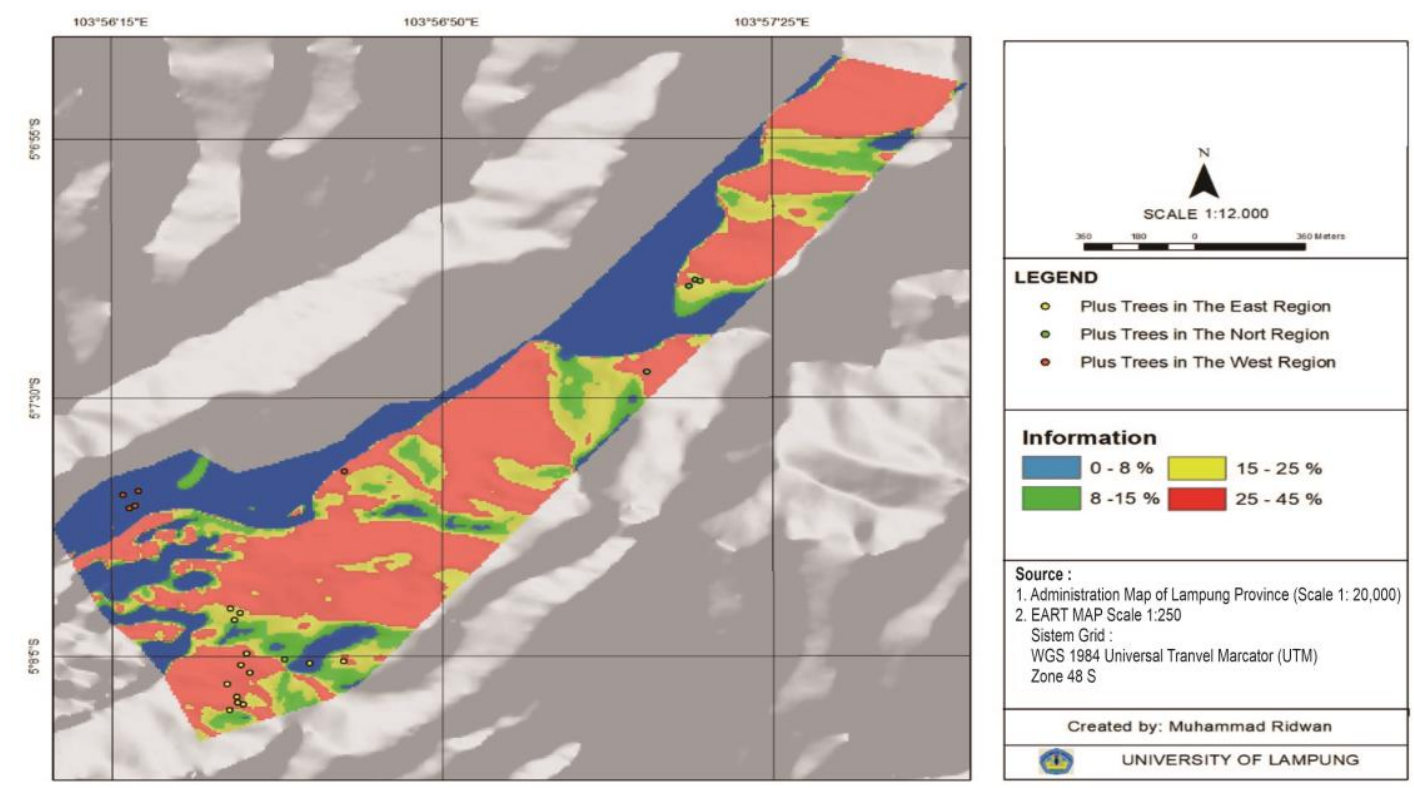

Figure 12 Distribution of the difference in the slopes of the 24 plus trees.

The characteristics of the place to grow other than slope and elevation are the type of soil. In general, the Repong Damar area has two types of soil, namely andosol and inceptisol. According to [8], damar mata kucing tree grows on specific soils andosol and inceptisol. The dominant soil type in the Repong Damar Pekon Penengahanan is the andosol soil type.

\section{Conclussion}

Based on the survey results and GIS analysis, there were 24 plus trees distributed in 3 sub-regions. In the eastern part there are 14 trees (58.3\%) bordering with Pekon Menyancang, in the northern part there are 5 trees (20.8\%) which borders with the Bukit Barisan Selatan National Park, and in the western part there are 5 trees $(20.8 \%)$ bordering with Pekon Way Nukak. Based on growing 
location condition, in the eastern part has a slope of 5-15\%, with an altitude of 41-121 masl. In the western part it has a slope of 5-7\%, with an altitude of 40-73 masl. In the northern part it has a slope of 5-15\%, with an altitude of 35-174 masl. The growing site conditions (slope and altitute) of three plus tree not influencing the number of plus tree distribution.

\section{REFERENCES}

[1] Kurniawan, D., Siti S.M. "Tipe repong damar dan hubungannya dengan dinamika gender rumah tangga petani repong damar," Jurnal Sosilogi Pedesaan, vol. 1, no. 2, pp. 85-99. 2013.

[2] Wijayanto, A. "Sifat Fisik Kimia Damar Mata Kucing (Shorea Javanica) Hasil Klasifikasi Mutu di Pasar Domestik," Undergraduated Thesis, Institut Pertanian Bogor, Bogor, 2012.

[3] Firdaus, A.B., Setiawan, A., and Rustiati, E.L. "Keanekaragaman Spesies Burung di Repong Damar Pekon Pahmungan Kecamatan Pesisir Tengah Krui Kabupaten Lampung Barat," Jurnal Sylva Lestari, vol. 2, no. 2, pp. 1-6. 2014.

[4] Bernardus, O. "Seleksi Kandidat Pohon Plus Salagundi (Roudholia Teysamnii) di Desa Simorangkir Julu Kabupaten Tapanuli Utara," Undergraduated Thesis, Universitas Sumatera Utara, Medan, 2018.

[5] Hasibuan, M., Indriyanto., and Riniarti, M. "Inventarisasi Pohon Plus dalam Blok Koleksi di Taman Hutan Raya Wan Abdul Rachman," Jurnal Sylva Lestari, vol. 1, no. 1, pp. 9-16. 2013.

[6] Novitasari, N. W., Nugraha, A., and Suprayogi, A. "Pemetaan Multi Hazards Berbasis Sistem Informasi Geografis di Kabupaten Demak Jawa Tengah," Jurnal Geodesi Undip, vol. 4, no. 4, pp. 181-191. 2015.

[7] Djamhuri, E., Supriyanto, I. Z., Siregar, U. Y., Siregar, A., Sukendro, S., Wilarso, P., Pamungkas, and Rahmat, S. Petunjuk Teknis Seleksi Pohon Induk. Intitut Pertanian Bogor, Bogor, 2006.

[8] Harianto, S.P., Dewi, B.S., and Rusita, Repong Damar. Plantaxia, Yogyakarta, 2016.

[9] Safe'i, R., Hardjanto, Supriyanto, and Sundawati, L. "Pengembangan Metode Penilaian Kesehatan Hutan Rakyat Sengon (Falcatania moluccana)," Jurnal Penelitian Hutan Tanaman, vol. 12, no. 3, pp. 175-187. 2015.

[10] Safe'i, R., Erl, H., Wulandari, C., and Kaskoyo, H. "Analisis Keanekaragaman Jenis Pohon Sebagai Salah Satu Indikator Kesehatan Hutan Konservasi," Jurnal Perennial, vol. 14, no. 2, pp. 32-36. 2018.

[11] Juanda., Abdurrani, M, and Reine S.W. "Seleksi Pohon Plus pada Areal Tegakan Benih IUPHHK-HA PT. Suka Jaya Makmur Kalimantan Barat," Jurnal Hutan Lestari, vol. 5, no. 4, pp. 927- 934. 2017.

[12] Anggara, D. "Produktivitas Penyadapan Damar Mata Kucing pada Berbagai Jumlah dalam Koakan di Krui Pesisir Barat Lampung," Undergraduated Thesis, Institut Pertanian Bogor, Bogor, 2014.

[13] Burhannudin, Samsul, and Abdurrani M. "Seleksi Pohon Induk Jenis Meranti (Shorea Spp) Pada Areal Tegakan Benih IUPHHK-HA PT. Suka Jaya Makmur Kabupaten Ketapang," Jurnal Hutan Lestari, vol. 4, no. 4, pp. 637 - 643. 2016.

[14] France, S., Rahmawaty, and Basyuni M. "Identifikasi Pohon Plus di Kecamatan Lumban Julu KPHL Model Unit XIV Toba Samosir," Peronema Forestry Science, vol. 5, no. 3, pp. 117-126. 2016.

[15] Yulizar, H. A. and Koesmaryandi, N. "Konservasi Damar Mata Kucing (Shorea Javanica) Berbasis Masyarakat di Zona Tradisional Taman Nasional Bukit Barisan Selatan." Jurnal Media Konservasi, vol. 19, no. 2, pp. 73 - 80. 2014. 